Article

\title{
EAF Slag Aggregate in Roller-Compacted Concrete Pavement: Effects of Delay in Compaction
}

\author{
My Ngoc-Tra Lam ${ }^{1,2, *}$, Saravut Jaritngam ${ }^{1}$ and Duc-Hien Le ${ }^{3}$ \\ 1 Department of Civil Engineering, Faculty of Engineering, Prince of Songkla University, Hat Yai, \\ Songkhla 90112, Thailand; jaritngam@gmail.com \\ 2 Faculty of Civil Engineering, Ho Chi Minh City Open University, 97 Vo Van Tan, District 3, \\ Ho Chi Minh City 700000, Vietnam \\ 3 Sustainable Developments in Civil Engineering Research Group, Faculty of Civil Engineering, \\ Ton Duc Thang University, Ho Chi Minh City 700000, Vietnam; leduchien@tdt.edu.vn \\ * Correspondence: ngoctramys@gmail.com
}

Received: 9 March 2018; Accepted: 3 April 2018; Published: 9 April 2018

\begin{abstract}
This study investigates the effect of delay in compaction on the optimum moisture content and the mechanical propertie s (i.e., compressive strength, ultrasonic pulse velocity, splitting tensile strength, and modulus of elasticity) of roller-compacted concrete pavement (RCCP) made of electric arc furnace (EAF) slag aggregate. EAF slag with size in the range of $4.75-19 \mathrm{~mm}$ was used to replace natural coarse aggregate in RCCP mixtures. A new mixing method was proposed for RCCP using EAF slag aggregate. The optimum moisture content of RCCP mixtures in this study was determined by a soil compaction method. The Proctor test assessed the optimum moisture content of mixtures at various time after mixing completion (i.e., 0, 15, 30, 60, and $90 \mathrm{~min}$ ). Then, the effect of delay in compaction on the mechanical properties of RCCP mixtures at 28 days of age containing EAF slag aggregate was studied. The results presented that the negative effect on water content in the mixture caused by the higher water absorption characteristic of EAF slag was mitigated by the new mixing method. The optimum water content and maximum dry density of RCCP experience almost no effect from the delay in compaction. The compressive strength and splitting tensile strength of RCCP using EAF slag aggregate fulfilled the strength requirements for pavement with 90 min of delay in compaction.
\end{abstract}

Keywords: delay in compaction; optimum moisture; mechanical properties; roller-compacted concrete pavement; EAF slag aggregate

\section{Introduction}

Electric arc furnace (EAF) slag is a by-product of steel production, which is generated during the manufacture of crude steel by the electric arc furnace process. The output of EAF slag was estimated at about $15-20 \%$ of crude steel production. Total world production of crude steel reached approximately 1560, 1650, and 1670 million tons in 2012, 2013, and 2014, respectively [1], leading to a huge quantity of EAF slag being produced every year. The use of EAF slag as a natural aggregate replacement in concrete has attracted much research over the last years [2-5], because the recycling of EAF slag has reduced the consumption of natural aggregates and the environmental impacts such as those due to a lack of waste storage areas and the pollution of soil. Many research works have demonstrated that natural aggregates in many types of concrete can be replaced by EAF slag. For example, Manso et al. [2] indicated that EAF slag aggregate created good concrete in terms of mechanical properties. Adegologe et al. [3] presented the findings that concrete made using EAF slag aggregate slightly improved the mechanical properties. The compressive strength and tensile strength of slag concrete increased by $9 \%$ and $3 \%$, 
respectively, in comparison to those of control concrete. Similarly, the improvement of mechanical properties was observed in Sekaran et al. research [4]. Besides, EAF slag also performed as a good aggregate in high-performance concrete. Faleschini et al. [5] showed that high-performance concrete containing 100\% EAF slag as the coarse aggregate had mechanical properties better than the reference concrete, including compressive strength, tensile strength, and elastic modulus. Review of the literature shows that EAF slag aggregate is eligible for use in concrete, but very few reports have studied roller-compacted concrete made with EAF slag aggregate. Roller-compacted concrete is a special concrete that is stiff and "no-slump". The application of roller-compacted concrete for pavements has rapidly increased in several decades because of its strength, durability, and cost efficiency. Because aggregate in a roller-compacted concrete pavement (RCCP) mixture comprises $75 \%$ of its volume, the substitution of traditional natural aggregate by EAF slag aggregate has become important for the development of sustainable infrastructure.

RCCP using EAF slag as coarse aggregate has produced pavement fulfilling strength requirements, as has been discussed previously [6]. Unlike natural aggregate replacement by EAF slag in conventional concrete and high-performance concrete, EAF slag as coarse aggregate substitute caused the decrease of RCCP strength (i.e., compressive strength and splitting tensile strength). The higher water absorption feature of EAF slag aggregate had a significant effect on the amount of water needed for the mixture, especially in low-water concrete such as RCCP. Therefore, the complement of water absorbed by EAF slag aggregate in RCCP is an effective solution for improving the strength.

Similar to asphalt pavement, RCCP is compacted with vibratory rollers to achieve a target density and homogeneous surface pavement. The timing of compaction is very important because of its effect on the density and strength of RCCP. Normally, RCCP should be compacted as soon as possible after its spreading. Furthermore, the time span between mixing (the timing of the addition of water in the mixture) and compaction of RCCP is usually within 45 to 90 min [7]. Moreover, some scholars have reported that there is an optimized compaction time. Karimpour [8] found that compacting the mixture at the optimized time resulted in the maximum compressive strength. In addition, the improvement of mechanical properties was observed in the RCCP mixture compacted at the optimized time [9]. The optimum time of compaction depended on materials, mixing design, and water-to-cement ratio in mixture.

In order to enhance RCCP strength, the aim of this study is to investigate the water absorption process of EAF slag aggregate. The water absorption function of EAF slag aggregate was used to propose a new mixing method for RCCP made with EAF slag aggregate. Futhermore, the effect of delay in compaction on the optimum moisture content and the mechanical properties of RCCP using EAF slag aggregate was assessed (i.e., compressive strength, ultrasonic pulse velocity, splitting tensile strength, and modulus of elasticity). In this work, the time span between mixing and compaction was $0,15,30,60$, and $90 \mathrm{~min}$.

\section{Testing Program}

\subsection{Materials}

\subsubsection{Cement}

Table 1 shows the chemical composition and physical characteristics of ordinary Portland cement (OPC) type I conforming to ASTM C150 used in this study [10]. 
Table 1. The chemical composition and physical characteristics of ordinary Portland cement (OPC).

\begin{tabular}{cc}
\hline Chemical Composition (\%) & OPC, Type I \\
\hline Silica $\left(\mathrm{SiO}_{2}\right)$ & 20.7 \\
Alumina $\left(\mathrm{Al}_{2} \mathrm{O}_{3}\right)$ & 4.5 \\
Ferric oxide $\left(\mathrm{Fe}_{2} \mathrm{O}_{3}\right)$ & 3.3 \\
Calcium oxide $(\mathrm{CaO})$ & 63.0 \\
Magnesium oxide $(\mathrm{MgO})$ & 1.8 \\
Sodium oxide $\left(\mathrm{Na}_{2} \mathrm{O}\right)$ & 0.10 \\
Potassium oxide $\left(\mathrm{K}_{2} \mathrm{O}\right)$ & 0.74 \\
Sulphuric anhydride $\left.(\mathrm{SO})_{3}\right)$ & 2.3 \\
Loss on ignition $(\mathrm{LOI})$ & 2.8 \\
\hline Physical Characteristics & \\
\hline Fineness $\left(\right.$ Blaine) $\left(\mathrm{m}^{2} / \mathrm{kg}\right)$ & 347 \\
Specific gravity & 3.14 \\
Initial setting time $(\mathrm{min})$ & 110 \\
Final setting time $(\mathrm{min})$ & 170 \\
Particle composition & $\mathrm{NA}$ \\
Retaining on $45 \mu \mathrm{mm}$ sieve $(\%)$ & \\
\hline Compressive Strength $\left(\mathrm{N} / \mathrm{mm}^{2}\right)$ & 14.6 \\
\hline 1 day & 26.2 \\
3 days & 33.0 \\
7 days & 43.0 \\
\hline 28 days &
\end{tabular}

Note: NA: not available.

\subsubsection{Aggregates}

Natural aggregate used in this study with the designed gradation as shown in Table 2 is crushed stone. EAF slag aggregate from Southern Vietnam with size in the range of 4.75-19 mm (Figure 1) reaching the requirements of ASTM C33 standard (Table 3) was used to replace natural aggregate in RCCP [11-14]. After leaving in an environmental condition for several months as a treatment process to reduce the volume expansion [15], the free $\mathrm{CaO}$ content of the EAF slag aggregate is less than $0.1 \%$ [6]. On the other hand, the expansion value of the EAF slag aggregate was $0.078 \%$, which is lower than the limit value $(0.5 \%)$ following ASTM D4792 [6,16]. Consequently, the EAF slag aggregate in this study exhibited the required volume stability.

Table 2. The suggested limits and the gradation of designed aggregate for the roller-compacted concrete pavement (RCCP) used in this study.

\begin{tabular}{cccc}
\hline \multirow{2}{*}{ Sieve Size } & \multicolumn{3}{c}{ Passing Mass (\%) } \\
\cline { 2 - 4 } & The Lower Limit & The Upper Limit & The Designed Gradation \\
\hline $19 \mathrm{~mm}$ & 95 & 100 & 100 \\
$12.5 \mathrm{~mm}$ & 70 & 95 & 83 \\
$9.5 \mathrm{~mm}$ & 60 & 85 & 73 \\
$4.75 \mathrm{~mm}($ No. 4$)$ & 40 & 60 & 54 \\
$2.36 \mathrm{~mm}$ (No. 8) & 30 & 50 & 41 \\
$1.18 \mathrm{~mm}$ (No. 16) & 20 & 40 & 30 \\
$600 \mu \mathrm{m}($ No. 30) & 15 & 30 & 22 \\
$300 \mu \mathrm{m}$ (No. 50) & 10 & 25 & 15 \\
$150 \mu \mathrm{m}$ (No. 100) & 2 & 8 & 10 \\
$<75 \mu \mathrm{m}$ (No. 200) & 0 & & 7 \\
\hline
\end{tabular}




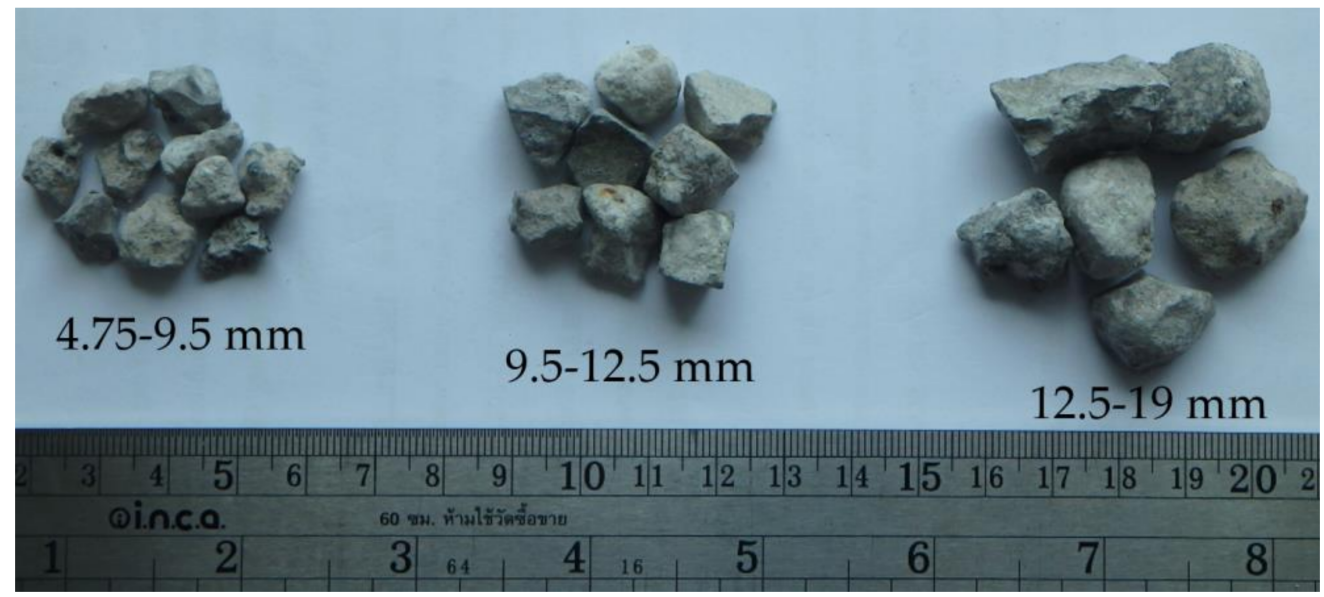

Figure 1. Electric arc furnace (EAF) slag aggregate used in this study.

Table 3. Physical properties of the crushed stone aggregate and EAF slag aggregate.

\begin{tabular}{cccc}
\hline \multirow{2}{*}{ Properties } & \multicolumn{2}{c}{ Crushed Stone } & EAF Slag \\
\cline { 2 - 4 } & $\begin{array}{c}\text { Fine Aggregate } \\
(\mathbf{0}-\mathbf{4 . 7 5} \mathbf{~ m m})\end{array}$ & $\begin{array}{c}\text { Coarse Aggregate } \\
(\mathbf{4 . 7 5 - 1 9} \mathbf{~ m m})\end{array}$ & $\begin{array}{c}\text { Coarse Aggregate } \\
(\mathbf{4 . 7 5}-\mathbf{1 9} \mathbf{~ m m})\end{array}$ \\
\hline Apparent specific gravity & 2.71 & 2.72 & 3.40 \\
Density (OD) $\left(\mathrm{kg} / \mathrm{m}^{3}\right)$ & 2609 & 2680 & 3085 \\
Density (SSD) $\left(\mathrm{kg} / \mathrm{m}^{3}\right)$ & 2644 & 2691 & 3176 \\
Bulk density $\left(\mathrm{kg} / \mathrm{m}^{3}\right)$ & 1493 & 1466 & 1686 \\
Water absorption $(\%)$ & 1.36 & 0.44 & 2.93 \\
Los Angeles abrasion & NA & 13.98 & 19.37 \\
value $(\%)$ & & & \\
\hline
\end{tabular}

Note: NA: not available.

\subsection{Testing Approaches and Sample Preparation}

This study is composed of three parts. In the first part, the water absorption process of the EAF slag aggregate was investigated. In the second part, the Proctor test determined the optimum moisture content of mixtures compacted at various time after mixing completion (i.e., 0, 15, 30, 60, and $90 \mathrm{~min}$ ). In the third part, the effect of delay in compaction on the mechanical properties of RCCP using EAF slag aggregate at 28 days of age was examined.

\subsubsection{The Water Absorption of EAF Slag Aggregate}

Because of the higher water absorption characteristic, the relationship between water absorption of the EAF slag aggregate and immersion time was investigated to mitigate the effect of this feature on the water content of the RCCP mixture. Ten samples of the EAF slag aggregate were prepared in accordance with ASTM C127 standard [11]. All samples were dried in the oven to constant mass at a temperature of $110 \pm 5{ }^{\circ} \mathrm{C}$ and cooled in air at room temperature for $2 \mathrm{~h}$. Then, ten samples were immersed in water at room temperature for $5 \mathrm{~min}, 10 \mathrm{~min}, 15 \mathrm{~min}, 30 \mathrm{~min}, 60 \mathrm{~min}, 90 \mathrm{~min}, 2 \mathrm{~h}, 4 \mathrm{~h}, 8 \mathrm{~h}$, and $24 \mathrm{~h}$ to determine the water absorption. Experiments were repeated five times to calculate the average value and the sample immersion times were changed after each test.

\subsubsection{Mixing Proportion of RCCP}

RCCP made of $100 \%$ EAF slag coarse aggregate (s-RCCP) and a reference RCCP made of $100 \%$ natural aggregate (r-RCCP) with $12 \%$ cement (Table 4 ) were subjected to the modified Proctor test 
(ASTM D1557) [17] after mixing completion at five levels of moisture content to determine the optimum moisture content of the mixture. According to ASTM D1557, the mixture is placed in five layers into the 6-in $(152.4 \mathrm{~mm})$ mold and compacted by 56 blows of a rammer per layer. After conducting the Proctor test, the density of mixture is determined to establish a relationship between the dry density and moisture content (the compaction curve). From the compaction curve, the optimum moisture content of the mixture was observed. Besides, four mixtures of r-RCCP and four mixtures of s-RCCP were subjected to delay in compaction of $15 \mathrm{~min}, 30 \mathrm{~min}, 60 \mathrm{~min}$, and $90 \mathrm{~min}$ to evaluate the optimum moisture content of mixtures at various times of compaction.

Table 4. Mixture proportions of RCCPs. r-RCCP: reference RCCP with 100\% natural aggregate; s-RCCP: $100 \%$ EAF slag coarse aggregate.

\begin{tabular}{ccccc}
\hline \multirow{2}{*}{ Mixture } & \multirow{2}{*}{ Cement $\left(\mathbf{k g} / \mathbf{m}^{\mathbf{3}}\right)$} & \multicolumn{2}{c}{ Coarse Aggregate $\left(\mathbf{k g} / \mathbf{m}^{\mathbf{3}}\right)$} & Fine Aggregate $\left(\mathbf{k g} / \mathbf{m}^{\mathbf{3}}\right)$ \\
\cline { 3 - 5 } & & EAF Slag & Crushed Stone & Crushed Stone \\
\hline r-RCCP & 274 & 0 & 842 & 1163 \\
s-RCCP & 282 & 867 & 0 & 1197 \\
\hline
\end{tabular}

Note: Cement is fixed at $12 \%$ of total weight of cement and oven-dried aggregates.

\subsubsection{Mechanical Properties of RCCP}

Ten mixtures containing the optimum moisture content were prepared to make the specimens. The standard cylinder specimens with diameter of $150 \mathrm{~mm}$ and height of $300 \mathrm{~mm}$ were molded by using a vibrating hammer conforming to ASTM C1435 [18]. After $24 \mathrm{~h}$ of casting, all specimens were removed from the mold and cured in tap water at the temperature of $23 \pm 2{ }^{\circ} \mathrm{C}$ until 28 days of age, to determine the mechanical properties of RCCP.

At 28 days of age, the measurement of ultrasonic pulse velocity transmitted from surface to surface of the cylinder specimen was conducted in accordance with ASTM C597 [19]. The pulse velocity is calculated by the transit time of the longitudinal stress wave through the sample received from the ultrasonic apparatus. Then, before the compressive strength testing conforming to ASTM C39 [20], the cylinder specimens underwent a capping procedure to make a plane surface for sampling. For splitting tensile strength testing (ASTM C496), the load is applied along the length of a cylindrical specimen at a constant rate in the range of 100 to $200 \mathrm{psi} / \mathrm{min}(0.7$ to $1.4 \mathrm{MPa} / \mathrm{min})$ until failure occurs [21]. Finally, the modulus of elasticity of r-RCCP and s-RCCP samples was measured following ASTM 469 [22]. All experiments were conducted on groups of three specimens to obtain the average value.

Table 5 shows the testing approaches and the quantity of samples in this study.

Table 5. The testing approaches and the quantity of RCCP samples used in this study.

\begin{tabular}{ccccc}
\hline No. & Testing Items & Sample Dimension $(\mathbf{m m})$ & Quantity of Sample & ASTM Standard \\
\hline 1 & Optimum moisture content & 6 -in $(152.4 \mathrm{~mm})$ diameter mold & 50 & ASTM D1557 \\
2 & Compressive strength & $150 \times 300$, cylinder & 30 & ASTM C39 \\
3 & Ultrasonic pulse velocity & $150 \times 300$, cylinder & - & ASTM C597 \\
4 & Splitting tensile strength & $150 \times 300$, cylinder & 30 & ASTM C496 \\
5 & Modulus of elasticity & $150 \times 300$, cylinder & 30 & ASTM C469 \\
\hline
\end{tabular}

\section{Results and Discussion}

\subsection{The Relationship between Water Absorption of EAF Slag Aggregate and Immersion Time}

The relationship between the water absorption ratio of the EAF slag aggregate and immersion time is shown in Figure 2. It was observed that the water absorption of the EAF slag aggregate occurred quickly within the first $5 \mathrm{~min}$, reaching $77.66 \%$ of the total water absorption. This behavior resulted 
from the water absorption of large pores in the EAF slag aggregate. After $5 \mathrm{~min}$, the water absorption took place at small pores, leading to water absorption rate reduction. The water absorption ratio was $81.16 \%, 83.06 \%$, and $86.86 \%$ after $10 \mathrm{~min}, 15 \mathrm{~min}$, and $30 \mathrm{~min}$, respectively (Table 6). After that, the water absorption happened very slowly and reached $88.94 \%$ after $60 \mathrm{~min}$. It can be seen that the water absorption of the EAF slag aggregate after $10 \mathrm{~min}$ of immersion comprised over $80 \%$ of the total water absorption.

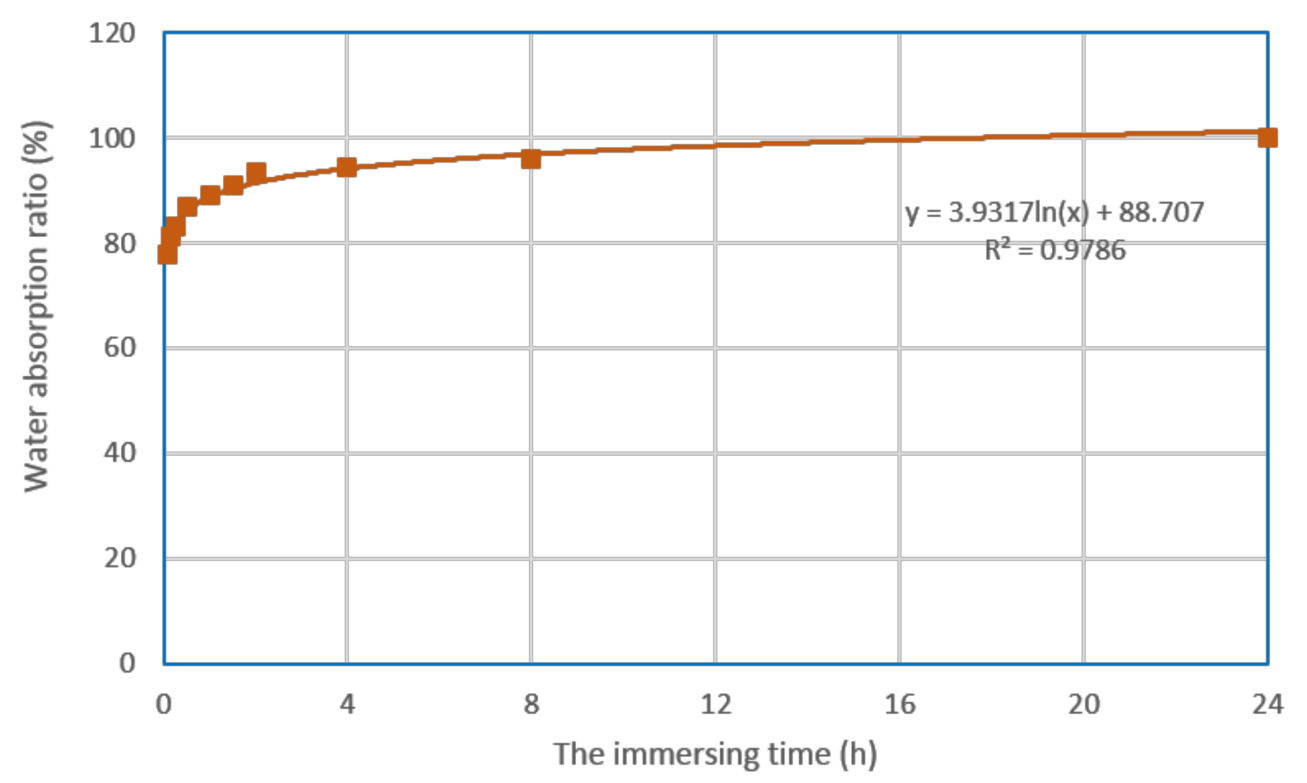

Figure 2. The relationship between the water absorption ratio of EAF slag aggregate and immersion time.

Table 6. The water absorption ratio of EAF slag aggregate and immersion time.

\begin{tabular}{cc}
\hline Immersion Time & \% of Total Water Absorption \\
\hline $5 \mathrm{~min}$ & 77.66 \\
$10 \mathrm{~min}$ & 81.16 \\
$15 \mathrm{~min}$ & 83.06 \\
$30 \mathrm{~min}$ & 86.86 \\
$60 \mathrm{~min}$ & 88.94 \\
$90 \mathrm{~min}$ & 91.10 \\
$2 \mathrm{~h}$ & 93.46 \\
$4 \mathrm{~h}$ & 94.25 \\
$8 \mathrm{~h}$ & 96.03 \\
$24 \mathrm{~h}$ & 100.00 \\
\hline
\end{tabular}

\subsection{Mixing Proportion of RCCP}

As discussion in Section 3.1, the EAF slag aggregate rapidly absorbed the water during the first $10 \mathrm{~min}$ of immersion. Therefore, a new mixing method of RCCP was designed in this study to mitigate the negative effect of the higher water absorption of the EAF slag aggregate on the mixing water dosage of the mixture. The new mixing method consists of two stages (Figure 3). In the first stage, $50 \%$ of the water dosage is mixed with aggregates within $10 \mathrm{~min}$, in order to allow most of the large pores of the EAF slag aggregate to absorb water. The second mixing stage is $5 \mathrm{~min}$, to create a homogeneous consistency of mixture. 
The first stage

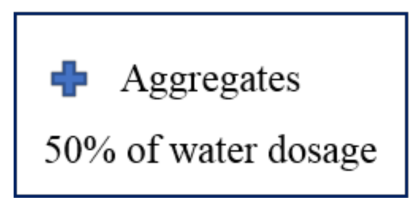

The second stage

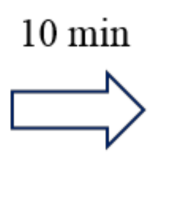

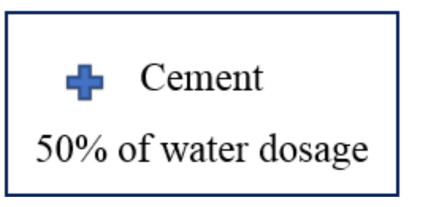

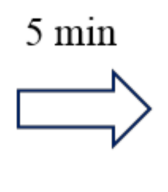

\section{Completion}

Figure 3. The new mixing method of RCCP in this study.

In this study, all RCCP mixtures were mixed following the new mixing method. After mixing completion, two mixtures (i.e., r-RCCP and s-RCCP) were compacted immediately, while eight mixtures were delayed in compaction for 15, 30,60, and $90 \mathrm{~min}$. The relationship between the dry density and moisture content of the RCCP mixtures was determined by Proctor testing results as listed in Table 7 .

Table 7. The relationship between the dry density and moisture content of RCCP mixtures at various time of compaction.

\begin{tabular}{cccc}
\hline Mixture & Delay Time (min) & $\begin{array}{c}\text { Dry Density }(\gamma)=\text { Moisture Content } \\
\text { Relationship (W) }\end{array}$ & $\mathbf{R}^{\mathbf{2}}$ \\
\hline r-RCCP & 0 & $\gamma=-12.95 W^{2}+179.55 W+1662.10$ & 0.94 \\
& 15 & $\gamma=-10.10 W^{2}+141.99 W+1776.10$ & 0.92 \\
& 30 & $\gamma=-12.09 W^{2}+171.85 W+1684.50$ & 0.96 \\
& 60 & $\gamma=-10.07 W^{2}+145.97 W+1747.80$ & 0.95 \\
s-RCCP & $\gamma 0$ & $\gamma=-17.56 W^{2}+282.18 W+1147.40$ & 0.97 \\
& 0 & $\gamma=-10.10 W^{2}+161.34 W+1734.90$ & 0.99 \\
& 15 & $\gamma=-21.46 W^{2}+344.76 W+1013.70$ & 0.99 \\
& 30 & $\gamma=-16.32 W^{2}+262.93 W+1314.00$ & 0.96 \\
& 60 & $\gamma=-16.41 W^{2}+265.31 W+1299.20$ & 0.93 \\
\hline 90 & $\gamma=-19.80 W^{2}+322.23 W+1071.20$ & 0.96 \\
\hline
\end{tabular}

According to Table 7, the optimum moisture content and maximum dry density of mixtures at various time of compaction were calculated, as listed in Table 8. It can be seen that the optimum moisture of s-RCCP $(7.99 \%)$ compacted immediately after mixing is higher than that of r-RCCP $(6.93 \%)$. This behavior resulted from the higher water absorption feature of the EAF slag aggregate. Most of the large pores of the EAF slag aggregate quickly absorbed the water when the EAF slag aggregate contacted the water in the first stage of the mixing process (Figure 3). From the optimum moisture content values, the total water needed for r-RCCP and s-RCCP were determined as $158 \mathrm{~L} / \mathrm{m}^{3}$ and $187 \mathrm{~L} / \mathrm{m}^{3}$, respectively. Hence, the effective water can be estimated as $138 \mathrm{~L} / \mathrm{m}^{3}$ for $\mathrm{r}-\mathrm{RCCP}$ and $146 \mathrm{~L} / \mathrm{m}^{3}$ for s-RCCP. Similar values for the effective water in RCCP have been found in a number of published works [23-25]. These values demonstrate that the new mixing method in this study helps complement the amount of water absorbed by the EAF slag aggregate. Furthermore, the increase of delay in compaction leads to the workability reduction of the mixture. Thus, the optimum moisture content of r-RCCP increases from $6.93 \%$ at $0 \mathrm{~min}$ to $8.04 \%$ at $90 \mathrm{~min}$. Besides, the optimum moisture of s-RCCP increases slightly from $7.99 \%$ at $0 \mathrm{~min}$ to $8.14 \%$ at $90 \mathrm{~min}$. The results stated that the workability reduction of the s-RCCP mixture is lower than that of r-RCCP, especially with $90 \mathrm{~min}$ of delay. This phenomenon may result from the water in the pore structure of the EAF slag aggregate being pushed out through compaction. As a result, the delay in compaction hardly affected the total water content of s-RCCP mixed by the new mixing method. 
Table 8. The optimum moisture and maximum dry density of RCCP mixtures at various time of compaction.

\begin{tabular}{ccccc}
\hline Mixture & Delay Time (min) & Optimum Moisture (\%) & Total Water $\left(\mathbf{L} / \mathbf{m}^{\mathbf{3}}\right)$ & Maximum Dry Density $\left(\mathbf{k g} / \mathbf{m}^{\mathbf{3}}\right)$ \\
\hline \multirow{4}{*}{ r-RCCP } & 0 & 6.93 & 158 & 2284 \\
& 15 & 7.03 & 160 & 2275 \\
& 30 & 7.11 & 162 & 2295 \\
& 60 & 7.24 & 165 & 2276 \\
s-RCCP & 90 & 8.04 & 183 & 2281 \\
& 0 & 7.99 & 187 & 2379 \\
& 15 & 8.03 & 188 & 2398 \\
& 30 & 8.06 & 189 & 2373 \\
& 60 & 8.08 & 190 & 2371 \\
\hline
\end{tabular}

On the other hand, the natural aggregate replacement by EAF slag leads to the increase of maximum dry density of s-RCCP because of the higher density of slag. The average maximum dry density of s-RCCP is $2381 \mathrm{~kg} / \mathrm{m}^{3}$, an increase of $4 \%$ in comparison with that of r-RCCP $\left(2282 \mathrm{~kg} / \mathrm{m}^{3}\right)$. Similar to the optimum water content, the delay in compaction has almost no effect on the maximum dry density of RCCP mixtures.

\subsection{Compressive Strength of $R C C P$}

Figure 4 shows the 28-day-age compressive strength of r-RCCP and s-RCCP at various times of compaction. The compressive strength of $\mathrm{r}-\mathrm{RCCP}$ is higher than that of s-RCCP at all compaction times. This may be a result of the bad quality of the interfacial transition zone between the EAF slag aggregate and cementitious matrix in low water concretes such as RCCP [6]. Moreover, the new mixing method in this study has enhanced the compressive strength of s-RCCP. For instance, s-RCCP compacted immediately after mixing by the new method obtained 43.54 MPa of compressive strength, whereas the compressive strength of s-RCCP reached $35.56 \mathrm{MPa}$ in a previous research work [6].

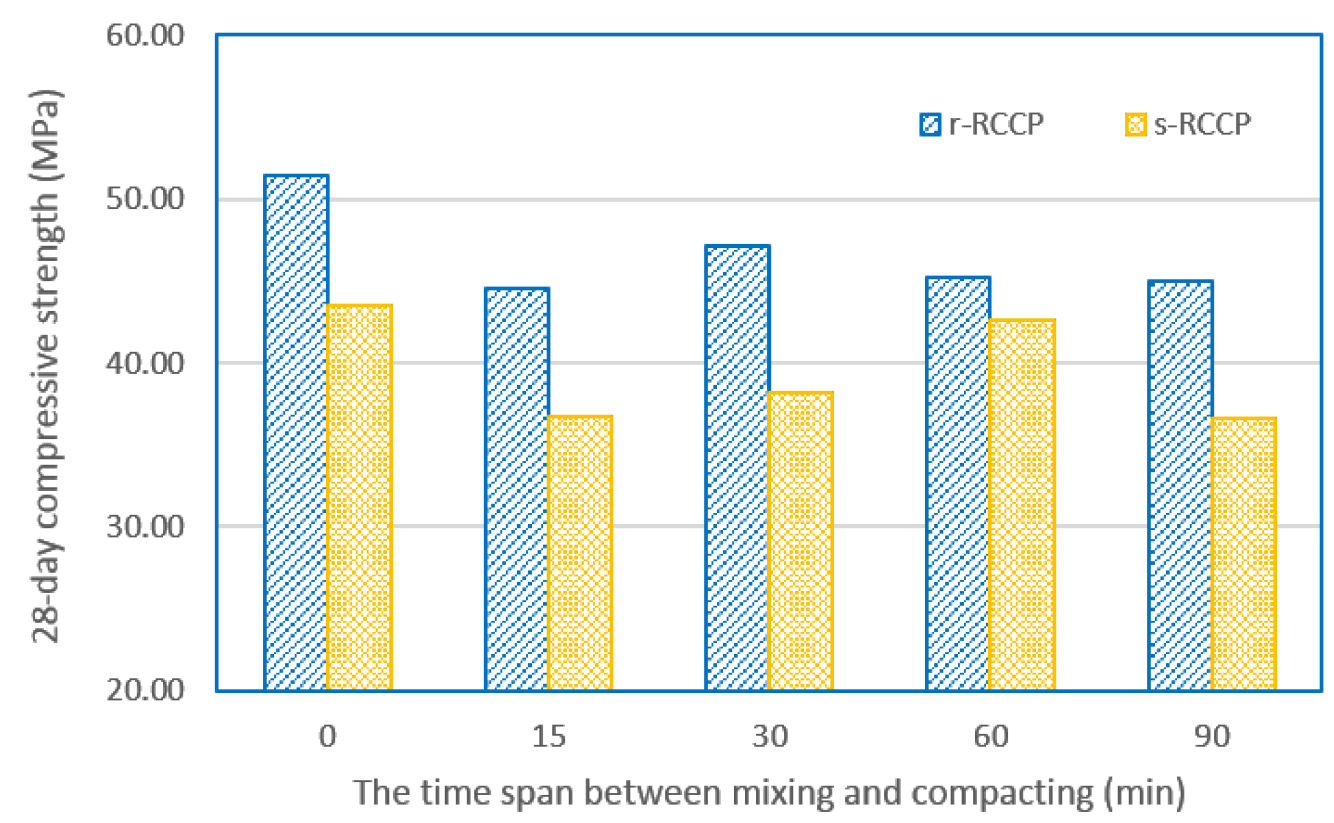

Figure 4. Compressive strength of r-RCCP and s-RCCP at various times of compaction.

As shown in Figure 4, the compressive strengths of r-RCCP and s-RCCP attained the highest value (i.e., 51.46 and $43.54 \mathrm{MPa}$, respectively) with compaction immediately after mixing completion. 
Good workability of mixtures resulted in the effective compaction process. Increasing the delay led to a compressive strength reduction. The compressive strength of r-RCCP at $15 \mathrm{~min}$ decreased by $13 \%$, and that of s-RCCP decreased by $16 \%$ in comparison to its compressive strength at $0 \mathrm{~min}$. However, both of r-RCCP and s-RCCP showed slightly improved compressive strength after 15 min of delay. For instance, the compressive strength of r-RCCP reached $47.18 \mathrm{MPa}$ at $30 \mathrm{~min}$, while that of s-RCCP reached $42.64 \mathrm{MPa}$ at $60 \mathrm{~min}$. This behavior may result from the formation of ettringite of the hydrated cement process. The formation of ettringite filled up the pores in structure concrete [26]. Consequently, the compressive strength increased with the compaction process in this period. Nevertheless, when the mixture was compacted in the period of the formation of the Calcium-Silicate-Hydrate (C-S-H) phase, it resulted in the crystallized product being destroyed. As a result, for r-RCCP and s-RCCP mixtures compacted at $90 \mathrm{~min}$, a decrease in compressive strength was observed.

Based on the results of this part, it is revealed that s-RCCP compacted at various times achieved compressive strengths in the range of $35 \mathrm{MPa}$ to $45 \mathrm{MPa}$. This range of values is popularly found in many research works on RCCP $[23,24,27,28]$. This result proved that s-RCCP can be delayed in compaction until $90 \mathrm{~min}$ while producing pavements fulfilling the strength requirement both in areas without freeze-thaw conditions (28 MPa) and in areas exposed to freeze-thaw conditions (31 MPa) [29].

\subsection{Ultrasonic Pulse Velocity (UPV) of RCCP}

Similarly to conventional paving concrete, the pulse velocities for $\mathrm{r}-\mathrm{RCCP}$ and s-RCCP in this study were in the range of $4500 \mathrm{~m} / \mathrm{s}$ to $4900 \mathrm{~m} / \mathrm{s}$ (Figure 5) [30]. According to UPV values, both the r-RCCP and s-RCCP specimens with various times of compaction are classified as "excellent" quality (UPV > $4500 \mathrm{~m} / \mathrm{s}$ ) [31]. r-RCCP provided higher UPV values than s-RCCP due to the higher compressive strength of r-RCCP. Moreover, there was a good relationship between UPV and compressive strength values, as presented by a best-fit exponential formula (Figure 6). Increasing UPV values accompanied the increase in compressive strength. In addition, the replacement of natural coarse aggregate in mixtures by EAF slag aggregate resulted in s-RCCP specimens with less uniformity than r-RCCP specimens.

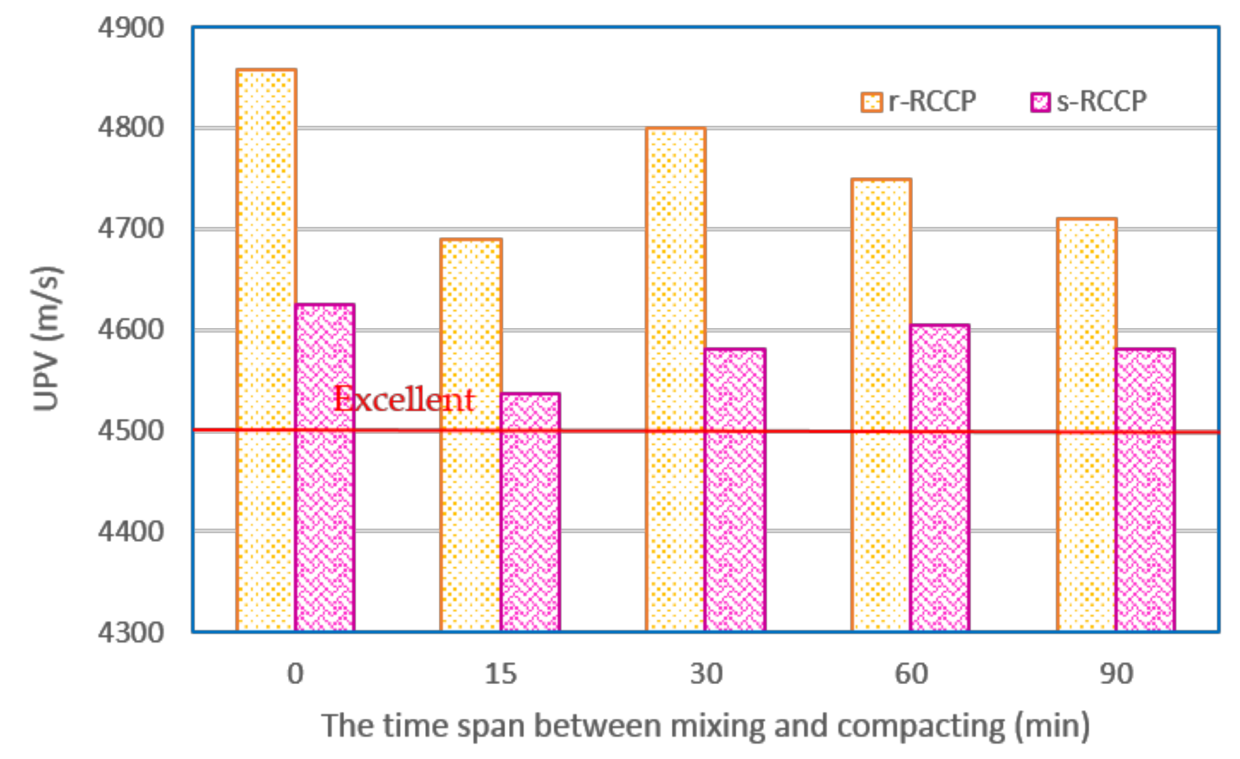

Figure 5. Measurement of ultrasonic pulse velocity (UPV) transmitted in compressive strength specimens of r-RCCP and s-RCCP at 28 days of age. 


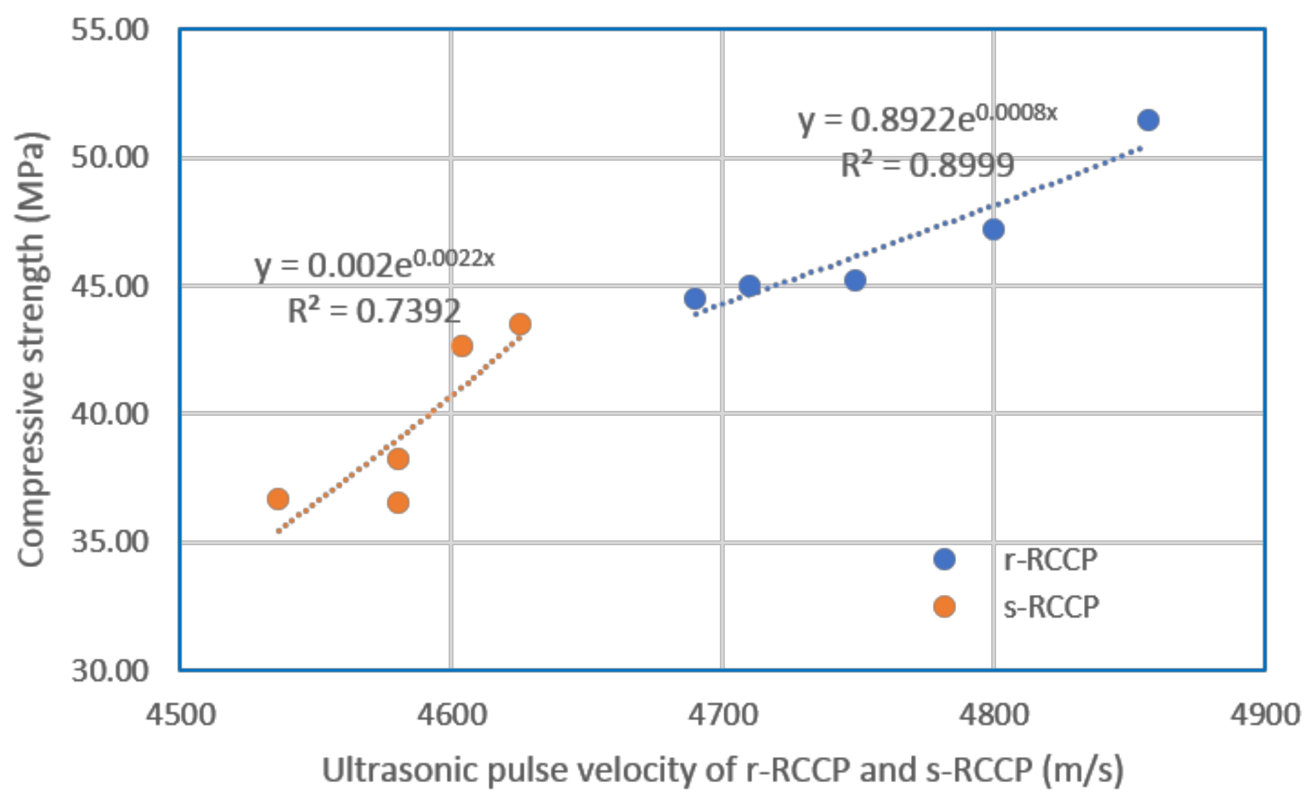

Figure 6. The relationship between compressive strength and ultrasonic pulse velocity of r-RCCP and s-RCCP.

\subsection{Splitting Tensile Strength of RCCP}

The splitting tensile strength of RCCP samples compacted at various times at 28 days of age are shown in Figure 7. r-RCCP attained the highest splitting tensile strength (4.81 MPa) with compaction immediately after mixing completion. Then, the delay in compaction led to the reduction of splitting tensile strength.

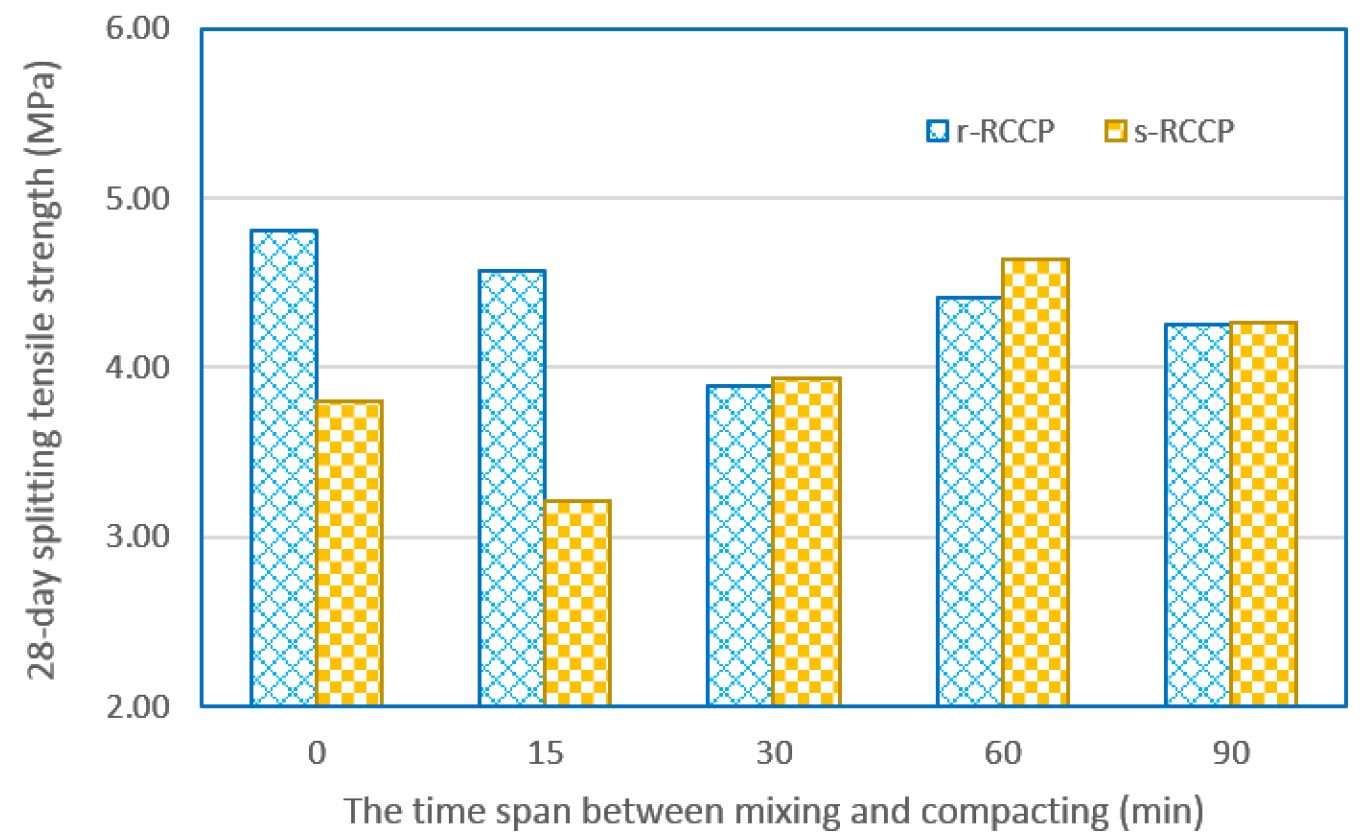

Figure 7. Splitting tensile strength of r-RCCP and s-RCCP at various times of compaction.

Splitting tensile strength values of s-RCCP at 28 days of age at various times of compaction were in the range of $3.2 \mathrm{MPa}$ to $4.6 \mathrm{MPa}$. This result is similar to that of conventional RCCP, which is generally between $3.1 \mathrm{MPa}$ to $4.2 \mathrm{MPa}$ [30]. In addition, it has been found that the splitting 
tensile strength of s-RCCP reached a peak (4.64 MPa) with compaction at $60 \mathrm{~min}$. The rough texture characteristic of the EAF slag aggregate improved the splitting tensile strength of s-RCCP. Besides, the filling of the pores by ettringite may be the cause of the strength increase when there was a delay in compaction [32]. Furthermore, the splitting tensile strength and compressive strength ratio of s-RCCP that was compacted after $30 \mathrm{~min}$ of delay is about 10 percent. This result is higher than a typical 8 to 9 percent of splitting tensile strength and compressive strength ratio of ordinary concrete [26]. The improvement of the splitting tensile strength of the EAF aggregate is appreciated in RCCP due to the load distribution characteristics of a rigid pavement.

\subsection{Elastic Modulus of RCCP}

As can be seen from Figure 8, the elastic modulus at 28 days of age of all RCCP mixtures in this study was in the range of $30 \mathrm{GPa}$ to $36 \mathrm{GPa}$. This range of values is found to be similar to that of conventional RCCP provided by a number of former scholars $[28,33,34]$. Therefore, the delay in compaction slightly affected the elastic modulus of RCCP. Both r-RCCP and s-RCCP achieved the highest values of elastic modulus ( $36 \mathrm{GPa}$ ) with compaction at $15 \mathrm{~min}$ after mixing. The lowest elastic modulus of r-RCCP ( $31 \mathrm{GPa}$ ) was obtained in the sample compacted at $30 \mathrm{~min}$, whereas that of s-RCCP (30 GPa) was obtained in the sample compacted immediately after mixing.

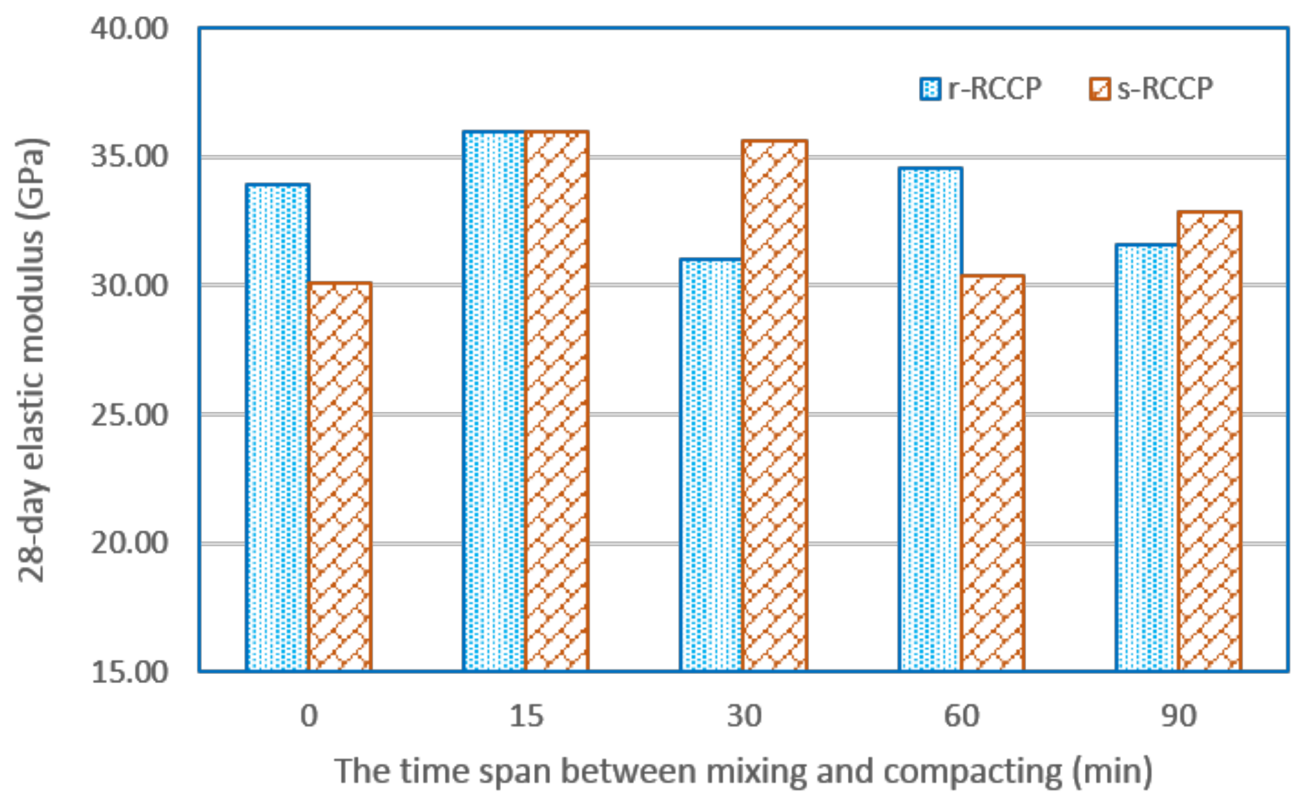

Figure 8. The elastic modulus of r-RCCP and s-RCCP at various times of compaction.

According to the CEB-FIP Model Code (1990) [26], the modulus of elasticity of concrete can be estimated from Equation (1):

$$
\mathrm{E}=b\left(f_{c} / 10\right)^{1 / 3}
$$

where $f_{\mathcal{c}}$ is the cylindrical compressive strength at 28 days of age (MPa) and the $b$ coefficient is $2.15 \times$ $10^{4}$ for normal concrete.

Based on the results and Equation (1), the $b$ coefficient of r-RCCP is $2.00 \times 10^{4}$ and the $b$ coefficient of s-RCCP is $2.09 \times 10^{4}$ (see Figure 9). Hence, the elastic modulus of r-RCCP and s-RCCP can be predicted by the compressive strength of samples at 28 days of age. 


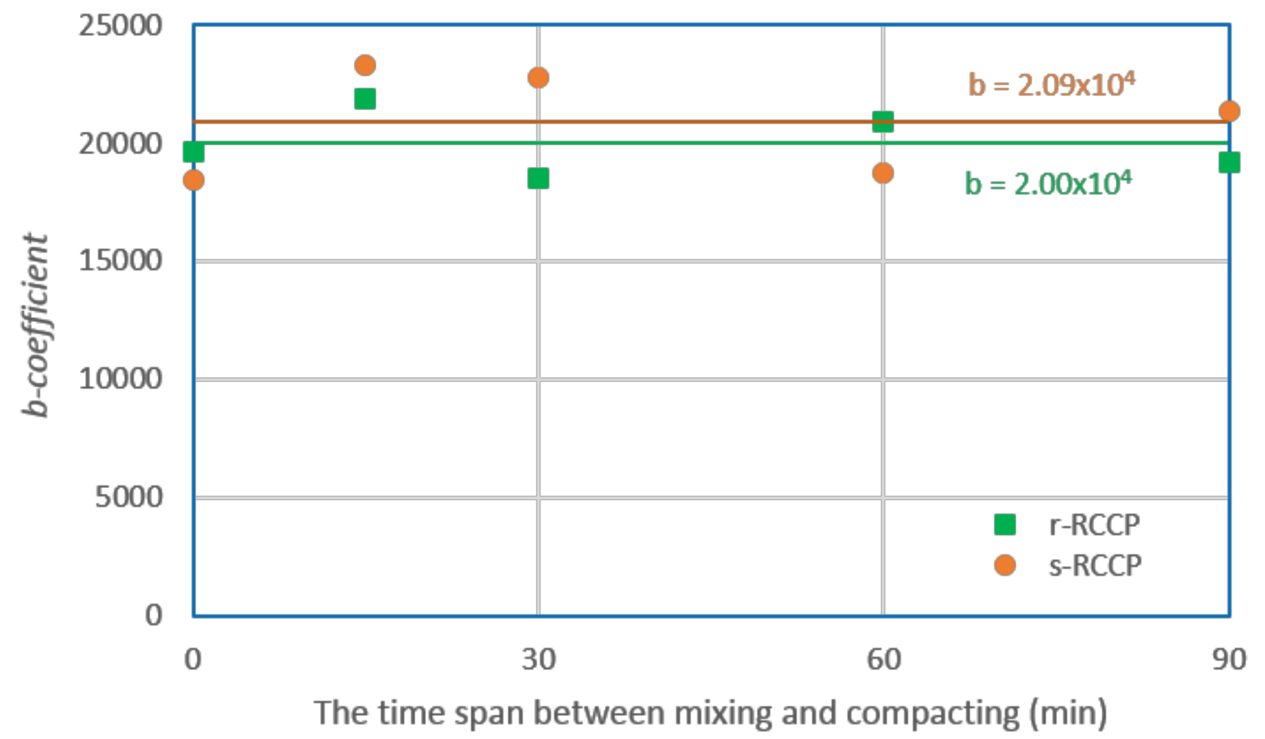

Figure 9. $b$ coefficient of r-RCCP and s-RCCP.

\section{Conclusions}

(1) The water absorption ratio of the EAF slag aggregate obtained over $80 \%$ of the total water absorption after $10 \mathrm{~min}$ of immersion in water.

(2) The new mixing method has mitigated a negative effect of the high water absorption feature of the EAF slag on the water of s-RCCP.

(3) The optimum water content of the s-RCCP mixture is higher than that of the r-RCCP mixture because of the higher water absorption of the EAF slag aggregate. Moreover, the optimum water content and maximum dry density of s-RCCP experiences almost no effect from the delay in compaction. The water content of the s-RCCP mixture mixed by the new method may maintain its workability for $90 \mathrm{~min}$.

(4) There was an improvement of s-RCCP compressive strength when the mixture was mixed by the new method. In addition, the compressive strength reached the highest value with compaction immediately after mixing. Increasing the delay in compaction led to a decline in the compressive strength of s-RCCP. However, 90 min of delay in compaction also produced s-RCCP fulfilling the strength requirement for pavements.

(5) The rough texture of the EAF slag aggregate caused the improvement of s-RCCP splitting tensile strength. Besides, the occurrence of the highest splitting tensile strength value of s-RCCP when delay in compaction was $60 \mathrm{~min}$ may be a result of the filling of the pores with ettringite.

(6) With UPV values $>4500 \mathrm{~m} / \mathrm{s}$, both the r-RCCP and s-RCCP specimens compacted at various times reached uniformity and "excellent" quality.

(7) The elastic modulus of r-RCCP and s-RCCP at 28 days of age was hardly affected by the delay in compaction. The range of values (30-36 GPa) is similar to that of conventional paving concrete. Furthermore, the elastic modulus of r-RCCP and s-RCCP can be predicted by the compressive strength of samples at 28 days of age.

Acknowledgments: This work was supported by the Higher Education Research Promotion and Thailand's Education Hub for Southern Regions of ASEAN Countries Project Office of the Higher Education Commission (Contract No. TEH-AC 032/2015) and the PSU.GS. Financial Support for Thesis scholarship.

Author Contributions: My Ngoc-Tra Lam and Duc-Hien Le designed the experiments. My Ngoc-Tra Lam conducted the experiments and wrote the paper. Saravut Jaritngam and Duc-Hien Le contributed discussion.

Conflicts of Interest: The authors declare no conflict of interest. 


\section{References}

1. Worldsteel Association. World Steel in Figures 2016. In Worldsteel Association; Worldsteel Association: Brussels, Belgium, 2016; pp. 3-30.

2. Manso, J.M.; Polanco, J.A.; Losañez, M.; González, J.J. Durability of concrete made with EAF slag as aggregate. Cem. Concr. Compos. 2006, 28, 528-534. [CrossRef]

3. Adegoloye, G.; Beaucour, A.L.; Ortola, S.; Noumowé, A. Concretes made of EAF slag and AOD slag aggregates from stainless steel process: Mechanical properties and durability. Constr. Build. Mater. 2015, 76, 313-321. [CrossRef]

4. Sekaran, A.; Palaniswamy, M.; Balaraju, S. A Study on Suitability of EAF Oxidizing Slag in Concrete: An Eco-Friendly and Sustainable Replacement for Natural Coarse Aggregate. Sci. World J. 2015, 2015. [CrossRef] [PubMed]

5. Faleschini, F.; Fernández-Ruíz, M.A.; Zanini, M.A.; Brunelli, K.; Pellegrino, C.; Hernández-Montes, E. High performance concrete with electric arc furnace slag as aggregate: Mechanical and durability properties. Constr. Build. Mater. 2015, 101, 113-121. [CrossRef]

6. Lam, M.N.T.; Jaritngam, S.; Le, D.H. Roller-compacted concrete pavement made of Electric Arc Furnace slag aggregate: Mix design and mechanical properties. Constr. Build. Mater. 2017, 154. [CrossRef]

7. ACI Committe 325. ACI 325.10R-95 Report on Roller-Compacted Concrete Pavements; Federal Highway Administration: Washington, DC, USA, 2001; pp. 1-32. reapproved.

8. Karimpour, A. Effect of time span between mixing and compacting on roller compacted concrete (RCC) containing ground granulated blast furnace slag (GGBFS). Constr. Build. Mater. 2010, 24, 2079-2083. [CrossRef]

9. Dasmeh, A.; Fakher, A.; Shekarchi, M.; Gharavy, M. The influence of compaction time on the mechanical properties of RCC. Int. J. Hydropower Dams 2000, 7, 60-63.

10. ASTM. C150-07 Standard Specification for Portland Cement; ASTM International: West Conshohocken, PA, USA, 2009.

11. ASTM. C127-07 Standard Test Method for Density, Relative Density (Specific Gravity) and Absorption of Coarse Aggregate; ASTM International: West Conshohocken, PA, USA, 2012.

12. ASTM. C128-07a Standard Test Method for Density, Relative Density (Specific Gravity), and Absorption of Fine Aggregate. In Annual Book of ASTM (American Society of Testing Material) Standards, 04.02; ASTM International: West Conshohocken, PA, USA, 2012.

13. ASTM. C131-06 Standard Test Method for Resistance to Degradation of Small-Size Coarse Aggregate by Abrasion and Impact in the Los Angeles Machine. In Annual Book of ASTM Standards, 4; ASTM International: West Conshohocken, PA, USA, 2000.

14. ASTM. C33/C33M-08 Standard Specification for Concrete Aggregates; American Society for Testing and Materials: Philadelphia, PA, USA, 2003.

15. Le, D.H.; Sheen, Y.N.; Bui, Q.B. An assessment on volume stabilization of mortar with stainless steel slag sand. Constr. Build. Mater. 2017, 155, 200-208. [CrossRef]

16. ASTM. D4792-06 Standard Test Method for Potential Expansion of Aggregates from Hydration Reactions; ASTM International: West Conshohocken, PA, USA, 2006.

17. ASTM. D1557-12 Standard Test Methods for Laboratory Compaction Characteristics of Soil Using Modified Effort (56,000 ft-lbf/ft3 (2,700 kN-m/m3)). In Annual Book of ASTM Standards, 4; ASTM International: West Conshohocken, PA, USA, 2000.

18. ASTM. C1435/C1435M-08 Standard Practice for Molding Roller-Compacted Concrete in Cylinder Molds Using a Vibrating Hammer. In Annual Book of ASTM Standards, 4; ASTM International: West Conshohocken, PA, USA, 1999.

19. ASTM. C597-02 Standard Test Method for Pulse Velocity through Concrete. In American Society for Testing and Materials; 100 Barr Harbor Drive: West Conshohocken, PA, USA, 2002.

20. ASTM. C39/C39M-14 Standard Test Method for Compressive Strength of Cylindrical Concrete Specimens; ASTM International: West Conshohocken, PA, USA, 1997.

21. ASTM. C496/C496M Standard Test Method for Splitting Tensile Strength of Cylindrical Concrete Specimens. In Annual Book of ASTM Standards 04.02; American Society for Testing and Materials Philadelphia: West Conshohocken, PA, USA, 1984. 
22. ASTM. C469-02 Standard Test Method for Static Modulus of Elasticity and Poisson's Ratio of Concrete in Compression. In Annual Book of ASTM (American Society of Testing Material) Standards, 04.02; ASTM International: West Conshohocken, PA, USA, 2002.

23. Rao, S.K.; Sravana, P.; Rao, T.C. Investigating the effect of M-sand on abrasion resistance of Fly Ash Roller Compacted Concrete (FRCC). Constr. Build. Mater. 2016, 118, 352-363. [CrossRef]

24. Modarres, A.; Hosseini, Z. Mechanical properties of roller compacted concrete containing rice husk ash with original and recycled asphalt pavement material. Mater. Des. 2014, 64, 227-236. [CrossRef]

25. Courard, L.; Michel, F.; Delhez, P. Use of concrete road recycled aggregates for Roller Compacted Concrete. Constr. Build. Mater. 2010, 24, 390-395. [CrossRef]

26. Mehta, P.K.; Monterio, P.J.M. Concrete-Microstucture, Properties and Materials, 3rd ed.; McGraw-Hill Companies, Inc.: New York, NY, USA, 2006.

27. Mardani-Aghabaglou, A.; Ramyar, K. Mechanical properties of high-volume fly ash roller compacted concrete designed by maximum density method. Constr. Build. Mater. 2013, 38, 356-364. [CrossRef]

28. Hesami, S.; Modarres, A.; Soltaninejad, M.; Madani, H. Mechanical properties of roller compacted concrete pavement containing coal waste and limestone powder as partial replacements of cement. Constr. Build. Mater. 2016, 111, 625-636. [CrossRef]

29. American Concrete Pavement Association. Roller-Compacted Concrete Pavements as Exposed Wearing Surface; American Concrete Pavement Association: Washington, DC, USA, 2014.

30. Tayabji, S.D.; Okamoto, P.A. Engineering properties of Roller-compacted concrete. Transp. Res. Rec. 1987, $1136,33-45$.

31. Whitehurst, E.A. Soniscope tests concrete structures. Int. Concr. Abstr. Portal. 1951, 47, 433-444.

32. Abu-Eishah, S.I.; El-Dieb, A.S.; Bedir, M.S. Performance of concrete mixtures made with electric arc furnace (EAF) steel slag aggregate produced in the Arabian Gulf region. Constr. Build. Mater. 2012, 34, 249-256. [CrossRef]

33. Rao, S.K.; Sravana, P.; Rao, T.C. Experimental studies in Ultrasonic Pulse Velocity of roller compacted concrete pavement containing fly ash and M-sand. Int. J. Pavement Res. Technol. 2016, 9, 289-301. [CrossRef]

34. Settari, C.; Debieb, F.; Kadri, E.H.; Boukendakdji, O. Assessing the effects of recycled asphalt pavement materials on the performance of roller compacted concrete. Constr. Build. Mater. 2015, 101, 617-621. [CrossRef] 